\title{
Huge increase for global environment?
}

\section{Tokyo}

INCREASED spending on research projects linked with the global environment stands out from the Japanese government's research budget for the next financial year, which begins on 1 April. Compared with the usually small yearly changes, some of the planned increases are dramatic.

Both the Ministry of International Trade and Industry (MITI) and the Science and Technology Agency (STA) have won substantial new funds for research on space and the global environment. The budget, now approved by the cabinet, has yet to be approved by the Diet, but the allocations to science and technology are unlikely to be changed.

Although MITI's overall research and development budget has been held to a modest increase of only 2.6 per cent barely enough to keep pace with inflation - it will be able to increase the funds available for research by using special accounts derived, for example, from taxes on oil and electricity. On the other hand, STA, which has a research budget twice as large, gets a healthy boost of 5.6 per cent.

MITI's problems arise because its general account has to decrease by 10 per cent each year under strict Ministry of Finance rules aimed at curbing government expenditures. STA's general account is not subject to such severe limits.

Most of MITI's spending of about $\$ 50$ million on the global environment - up nearly 20 per cent on last year - will go to

JAPANESE SCIENCE BUDGET FOR 1991

Ministry of International Trade and Industry (MITI) Thousand \% Change million yen from 1990 $258.1+2.6$ $28.6^{*}+10.0$ $7.9+5.4$ $14.3+1.8$ $\begin{array}{rr}14.3 & +1.8 \\ 6.7 & +21.8\end{array}$ $29.9-24.5$

$11.9+2.4$

$9.9+20.7$

$7.2+2.9$

0.1

IMS

Elucidation of biological functions

Science and Technology Agency (STA)

Total R \& $D$ budget

Special promotion funds

Space

Nuclear energy (ITER)

SOR (Spring-8)

Ocean research

ERATO

Human Frontier Science Program

Green Planet Project

Sakigake Research 21

* Budget shared with Ministry of Posts and Telecommunications

t includes 1.511 million yen from MITl budget $+17.4$ $+145.4$ $+18.3$ government/industry projects to develop environmentally friendly technology such utilization of carbon dioxide. These prowill be coordinated by MITI's new Institute of Innovative Technol, in 1992 , in the Kansai science city (ween Osaka, Nara and Kyoto. As well 's direct support, RITE has won governments and industry, making it probably the largest project ever launched y MITI.

There is also an enormous increase for STA's 'Green Planet' project, aimed at observing and monitoring the Earth's enmore than 50 per cent of the project’s budget, or $¥ 5,737$ million, will go to the development of the Advanced due to be launched in 1995. There is also a ignificant increase in the agency's fund Pacific and Arctic Oceans.

Apart from the new satellite, the main eason for the increase in STA's budget for space is a dramatic increase in outlays Japanese participation in the US space ( million) this year

MITI's budget is also brightened by a 10 per cent increase in funds for the Japan Key Technology Centre, operated jointly with the Ministry of Posts and Telecommunications (MPT). The centre is funded with the dividends of government-held shares of the recently privatized Nippon Telegraph and Telephone Corporation (NTT). Two of the key projects the centre supports are MITI's Protein Engineering Research Institute in Osaka and MPT's Advanced +9.0 Telecommunications Research Institute (ATR) in Kansai science city, which are among the best financed and best equipped research institutes in Japan.

Ironically, the fall in the value of NTT shares last year in the stock market slump has brought about this year's increase of funds for the centre. The government put pressure on NTT to increase its dividend payments to compensate shareholders for the enormous loss in value of their shares. But
MITI officials fear that the increased dividends will be just a one-off event.

Both MITI and STA continue to pour extra money into international research projects. A MITI project to develop a hypersonic commercial aircraft in collaboration with European and US aerospace companies, including Rolls-Royce of the United Kingdom and Pratt and Whitney of the United States, gets more than 20 per cent extra, or $¥ 6,700$ million ( $\$ 50$ million) next year. A final agreement covering intellectual property rights for the project is expected shortly.

Both MITI and STA have increased their budgets for the Human Frontier Science Program, which distributes grants and fellowships to international teams for research on the brain and molecular biology. MITI's Intelligent Manufacturing System project to develop the automated factories of the future gets extra funds for an international feasibility study.

The budget for STA's ERATO projects continues to grow rapidly. And the agency this year will launch a new project, Sakigake Research 21, modelled on ERATO, that will disperse grants to individual researchers rather than teams.

Twelve individuals will be selected in 1991 and will each receive an average of $¥ 60$ million $(\$ 450,000)$ over three years to support research on bioscience, material science and electronics. Similarly, MITI is expanding its budget for a programme modelled on the Human Frontier project that distributes domestic grants for elucidation of biological functions.

David Swinbanks

\section{ACADEMIC FREEDOM \\ Back to flesh}

\section{Washington}

IT may not seem much to crow about, but Canadian researcher Philippe Rushton reports that he will now be allowed to teach his classes in person. For the embattled psychologist, whose controversial work on race, sexuality and intelligence has drawn wide protest in Canada, permission to face his students means the end of a semester of videotape presentations.

Pre-taped lectures have been Rushton's only classroom appearances since university officials, fearful of demonstrations, banished him from live teaching last year (see Nature 347, 6; 1990). Perhaps for just that reason, demonstrations did not become a major problem, and in the name of academic freedom, some students and faculty rallied behind him.

The end, however, may not yet be in sight. Rushton also reports that he is hard at work on a book covering the subjects that earned him a vice squad investigation last year. "It would be naive to believe that it will be smooth sailing from now on", he observes.

Christopher Anderson 